\title{
EFFECT OF EUROPE STRATEGY 2020 AND NATIONAL REGIONAL POLICIES ON SMART CITIES DEVELOPMENT
}

\author{
Sostar Marko, Doctor of Economy, Professor, \\ marko.sostar.hr@gmail.com, \\ Andrlic Berislav, Doctor of Economy, Professor, \\ bandrlic@vup.hr, \\ Polytechnic in Pozega, Croatia \\ Popov Oleg, PhD., Associate Professor, \\ oleg.a.popov@gmail.com, ORCID: 0000-0002-0573-9408: \\ Odessa State Academy of Civil Engineering and Architecture
}

\begin{abstract}
The Europe 2020 strategy is the EU's agenda and innovation policy for growth and jobs for the current decade. It emphasizes smart, sustainable and inclusive growth as a way to overcome the structural weaknesses in Europe's economy, improve its competitiveness and productivity and underpin a sustainable social market economy.

One of the key goals of regional development in urban area is to promote climate change and increase the usage of energy from renewable energy sources. The aim of this scientific research is to show how important cities are for improving climate conditions and reducing reverse environmental impact.
\end{abstract}

Keywords: EU funding, Europe 2020, smart city, regional development, strategy.

Introduction. In the 21 st century, everyone has a smart phone, clock or tablet, we are connected to the internet 24 hours a day, but most of our cities are still organized as if the landline was the last word of the technique. Today, around 4 billion people live in cities. There will be more than $70 \%$ of people in 2050 living in cities and urban areas whose infrastructure is already on the overload. Electricity, transportation, plumbing, garbage collection, wastewater disposal; all this is infrastructural problems that will grow further in years ahead, while citizens increasingly feel alienated from each other. The solution is so-called innovation policy of smart cities - using the existing and advanced technologies to try to change the way we live, travel and spend their free time in cities. It is about innovations that often appear obvious once they introduce them and become so widely accepted that citizens quickly forget what life was like without them.

The Europe 2020 strategy put forward by the Commission sets out a vision of Europe's social market economy for the 21st century. It shows how the EU can come out stronger from the crisis and how it can be turned into a smart, sustainable and inclusive economy delivering high levels of employment, productivity and social cohesion. To deliver rapid and lasting results, stronger economic governance will be required. The European Commission launched a new 10-year economic strategy, called Europe 2020, to boost European economy and promote a smart, sustainable and inclusive growth, based on a greater coordination of national and European economic policy. The initiative wants to overcome the weaknesses of the Lisbon strategy and paving the way for the creation of new jobs and a better quality of life. Europe 2020 sets out a vision of Europe's social market economy for the 21st century and puts forward three mutually reinforcing priorities:

- Smart growth: developing an economy based on knowledge and innovation.

- Sustainable growth: promoting a more resource efficient, greener and more competitive economy.

- Inclusive growth: fostering a high-employment economy delivering social and territorial cohesion.

SMART CITIES - NEW AGE OF THINKING. Explosive population growth and high 
population densities in urban areas have created a number of social issues such as political and social unrest, energy scarcity, and a wider education gap between rich and poor [1].

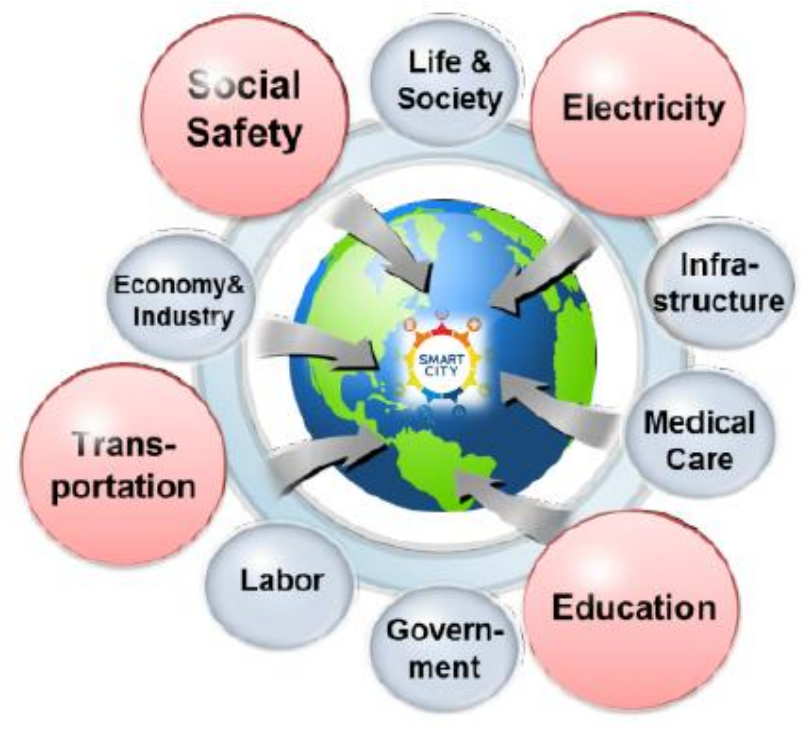

Fig.1. Challenges of the cities today

Source: Institute for Information Industry, 2017 [1]

There are many challenges of cities today. The problems are detected in insufficient food safety and regional sanitary, criminal gangs, drug trafficking, and protest marches have put society's safety in jeopardy, gap between rich and poor is getting wider amid sluggish industrial growth, urban traffic congestion; high road maintenance costs, high unemployment rate, electricity supply is either insufficient or unstable; inefficient energy consumption, insufficient infrastructure, epidemic outbreak consumes more and more medical resources, the gap between urban and rural education is getting wider and the support for lowincome minority students is required, poor administrative efficiency and high fiscal deficit [1].

A common definition of a 'smart city' has not yet been determined. Many authors use various definitions to clarify what is a 'smart city'. Authors define it as a city that bets a lot on the quality of living and where the citizens are involved as main actors in decision processes [2]. Cities have a duty to fulfil the needs of their citizens through various systems. The types of systems are by no means exhaustive, but certainly include public services such as light management, traffic and transport organization, waste and water management, administration policies, security, energy sustainability and information services. Regular cities operate and supervise every system as a separate unit, which in return produces more costs for taxpayers with slight to no improvements in the quality of living. On the contrary, 'smart cities' use Information and Communications Technologies (ICT) with Internet of Things (further: IOT) to create connections and interactions between some or all of the systems, cutting expenses and improving the quality of life for citizens during the process [3]. The term smart city is an umbrella concept that contains a number of subthemes such as smart urbanism, smart economy, sustainable and smart environment, smart technology, smart energy, smart mobility, smart health, and so on. The concept of smart city goes beyond the definitions of information cities, digital cities, and intelligent cities, because it contextualizes technology to be used in favor of systems and services for people [4].

As the main goal of a Smart City is to provide its citizens with a comfortable and a happy life, its mission is to work out a careful and successful Smart City development plan which would dramatically improve their citizens' quality of life. In addition it would encourage business to invest, and create a sustainable urban environment for good living. There are four essential elements of a Smart City [5]:

- Efficient utilization of networked infrastructure to improve economic and policy efficiency and enable social, cultural and urban development; these infrastructures include all types and categories, not only from technological perspective such as communication channels and broadband, but all other physical and even logical networking, connections and architectures.

- Provide a vision and a strategy for creating the competitive city in benefiting and capturing the opportunities of ICTs to increase local prosperity and competitiveness. A carefully written and adopted vision for the Smart City, and its mission have to be the source of motivation for policy and strategic formulation of policies and strategies to be adopted in the city transformation into a smart one.

- Provide and support the multi-stakeholder, multi-sector, and multi-level urban perspective towards competitiveness and sustainability. This is an essential partnership policy that will have to be effective and fruitful in order to make sure that the city is capable of successfully transforming into a smart one. 
- Able to sustain continuous efforts to adapt, innovate and use new ways to provide sustained and enhanced social capital of urban development. Although this statement could be interpreted in versatile viewpoints, yet basic keywords are unifying help to design creative ways of implementing such efforts. These are: Adapt, Innovate, Social Capital, and Urban Development.

The governance of Smart Cities should be «smart» in the sense that it should include major roles of governance. It is argued that smart economy sector is not different from economy, neither has it insinuated that economic development should be made in a different way. The "smart economy» is used here to highlight the technology component of the economic development. So adopting economic initiatives that are based or use or integrate smart technologies is referred to here as smart economy. People are the most important part of any city. Since long ago, this fact was well recognized. Not only this, but what kind of people does the city have5 is very important in determining the success and growth of a Smart City. The urban setting of the habitat is a most important component that helps provide a high quality and a happy life for the dwellers. This kind of setting provides for what is known as smart living. It includes environment, green economy, proper utility services and so on [5].

EUROPE STRATEGY 2020 - MEASURES FOR DEVELOPMENT. Europe 2020 is the EU's growth strategy for the new decade. The Union has set five ambitious objectives - on employment, innovation, education, social inclusion and climate/energy - to be reached by 2020 . Each Member State will adopt its own national targets in each of these areas. Concrete actions at EU and national levels will underpin the strategy.

Much like most other regions across the world, Europe is going through a period of transformation. The global economic crisis has wiped out years of economic and social progress and exposed structural weaknesses in its economy. Meanwhile, various long-term challenges such as globalization, pressure on natural resources and an ageing population are intensifying. The structural weaknesses in Europe's economy exposed by the crisis can only be addressed by moving ahead with structural reforms: reforms that are based on national efforts, but build on European assets such as the single market, the common trade policy and other EU-level policies. If we want to sustain the model of the European social market economy in the current challenging climate, then Europe will also need to be more competitive. In order to tackle these issues, the European Union and its Member States launched in 2010 a strategy for sustainable growth for the coming decade: the Europe 2020 strategy. The strategy deals both with short-term challenges linked to the crisis and the need for structural reforms through growth-enhancing measures needed to make Europe's economy fit for the future [6].

The EU has set five ambitious objectives - on employment, innovation, education, social inclusion and climate/energy - to be reached by 2020. In concrete terms these are [7]:

- Ensuring $75 \%$ employment of 20-64-year-olds.

- Getting $3 \%$ of the EU's GDP invested into research and development.

- Limiting greenhouse gas emissions by $20 \%$ or even $30 \%$ compared to 1990 levels, creating $20 \%$ of our energy needs from renewables and increasing our energy efficiency by $20 \%$.

- Reducing school dropout rates to below $10 \%$, with at least $40 \%$ of 30-34-year-olds completing tertiary education.

- Ensuring 20 million fewer people are at risk of poverty or social exclusion.

ENVIRONMENTAL CHALLENGES AND GLOBAL WARMING. Our environment is constantly changing. With a massive influx of natural disasters, warming and cooling periods, different types of weather patterns and much more, people need to be aware of what types of environmental problems our planet is facing. Global warming has become an undisputed fact about our current livelihoods; our planet is warming up and we are definitely part of the problem. However, this isn't the only environmental problem that we should be concerned about. All across the world, people are facing a wealth of new and challenging environmental problems every day. Current environmental problems make us vulnerable to disasters and tragedies, now and in the future. We are in a state of planetary emergency, with environmental problems piling up high around us. Unless we address the various issues prudently and seriously we are surely doomed for disaster. Current environmental problems require urgent attention [8]. 

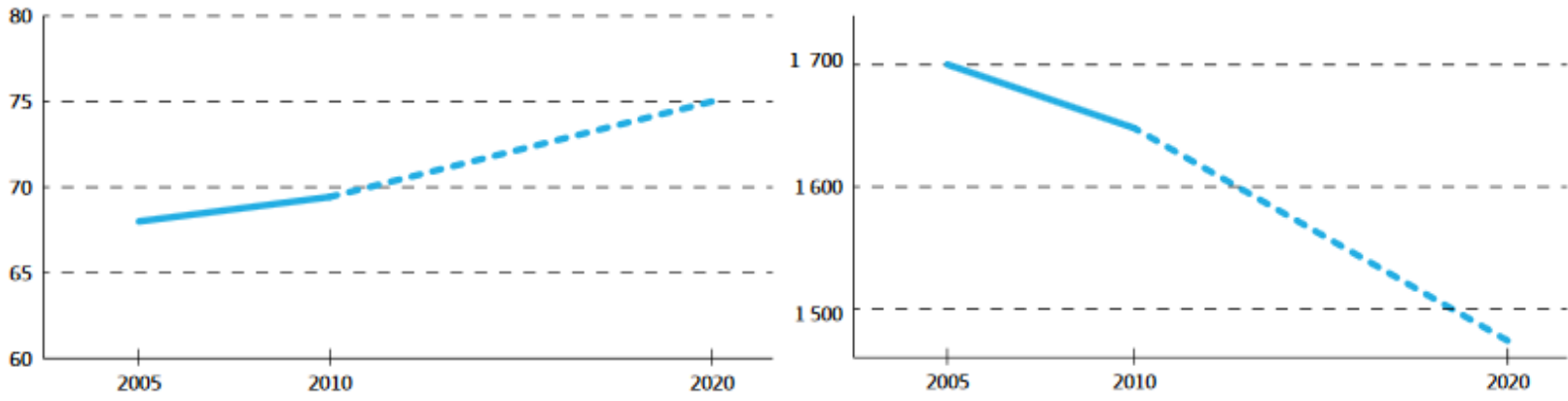

Share of 20-64-year-olds in work

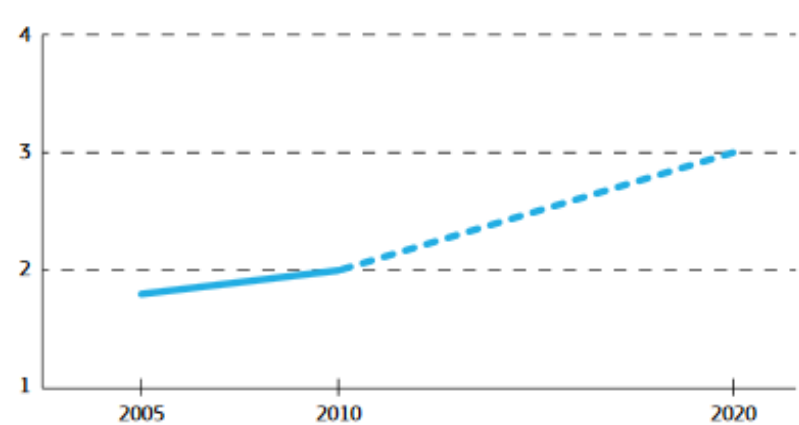

REDUCE THE NUMBER OF SCHOOL DROPOUTS TO UNDER $10 \%$

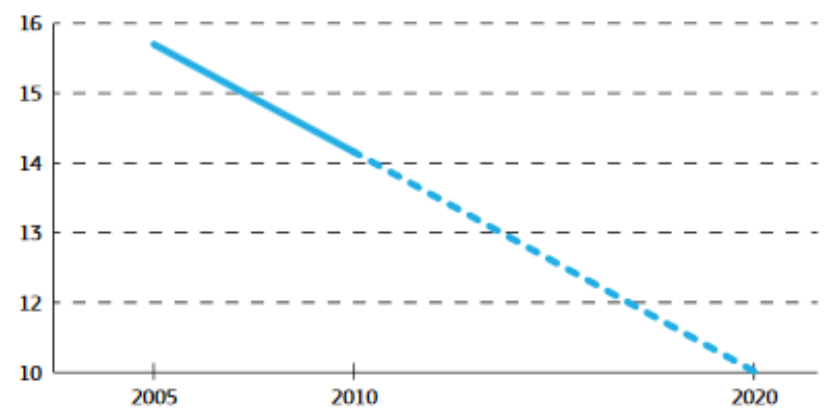

REDUCE GREENHOUSE GAS EMISSIONS BY $20 \%$

COMPARED TO 1990

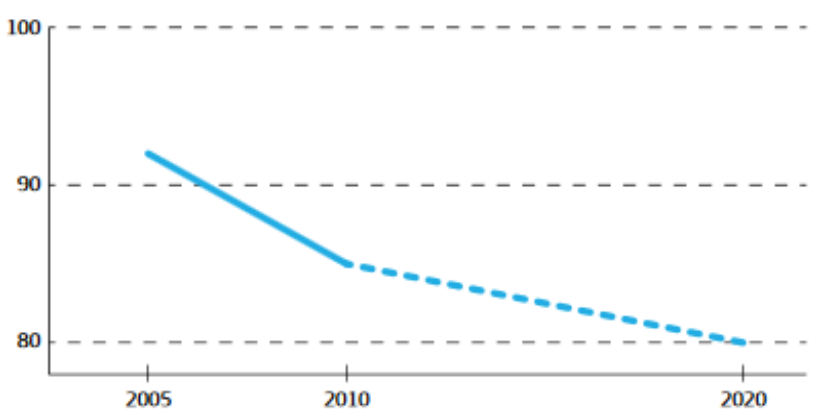

ENSURE THAT AT LEAST $40 \%$ OF 30-34-YEAR-OLDS HAVE A HIGHER EDUCATION

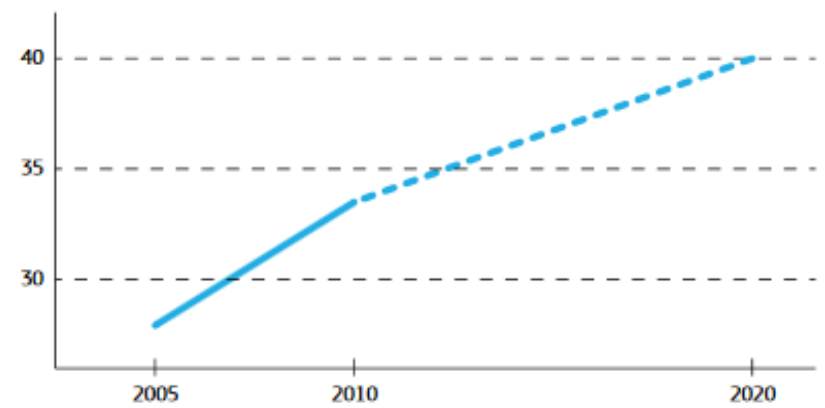

INCREASE THE SHARE OF RENEWABLE ENERGY TO $20 \%$

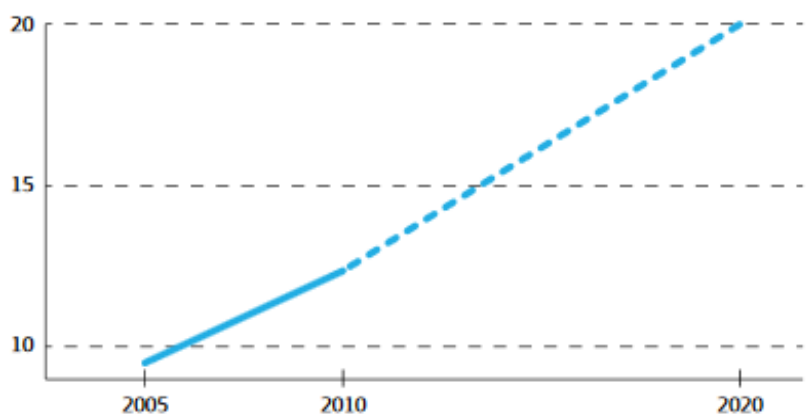

Fig. 2. Europe's targets for 2020

Source: European Commission, 2010 [6]

Pollution of air, water and soil take a huge number of years to recover. While water contamination is brought about by oil slicks, acid rain, and urban sprawl; air contamination is created by different gasses and poisons discharged by businesses and manufacturing plants and burning of fossil fills; soil contamination is majorly created by mechanical waste that takes supplements out of the soil. 
Table 1 - Environmental challenges. Source: Conserve Energy Future, 2016 [8]

\begin{tabular}{|l|l|}
\hline Air Pollution & $\begin{array}{l}\text { Ozone Layer } \\
\text { Depletion }\end{array}$ \\
\hline Water Pollution & Mining \\
\hline Soil and Land Pollution & $\begin{array}{l}\text { Natural Resource } \\
\text { Depletion }\end{array}$ \\
\hline Climate Change & Natural Disasters \\
\hline Global Warming & Nuclear Issues \\
\hline Deforestation & $\begin{array}{l}\text { Loss of Endangered } \\
\text { Species }\end{array}$ \\
\hline $\begin{array}{l}\text { Increased Carbon } \\
\text { Footprint }\end{array}$ & Acid Rain \\
\hline Genetic Modification & Agricultural Pollution \\
\hline Effect on Marine Life & $\begin{array}{l}\text { Light and Noise } \\
\text { Pollution }\end{array}$ \\
\hline Public Health Issues & Urban Sprawl \\
\hline Overpopulation & Medical Waste \\
\hline Loss of Biodiversity & Littering and Landfills \\
\hline $\begin{array}{l}\text { Household and Industrial } \\
\text { Waste }\end{array}$ & \multicolumn{1}{|l}{} \\
\cline { 1 - 2 } &
\end{tabular}

Clean drinking water is turning into an uncommon thing. Water is turning into a monetary and political concern as the human populace battles for this need. Waste from industrial and agricultural activities pollute the water that is used by humans, animals and plants. Land pollution simply means degradation of earth's surface as a result of human activities like mining, littering, deforestation, industrial, construction and agricultural activities. Land pollution can have huge environmental impact in the form of air pollution and soil pollution which in turn can have adverse effect on human health. Climate change is yet another environmental concern that has surfaced in last couple of decades. Environmental change has different destructive impacts that include, but are not limited to, the melting of polar ice, change in seasons, new sicknesses, and change in general climate situation. Environmental asset abuse is also an important environmental concern. Fossil fuel utilization brings about discharge of greenhouse gasses, which causes environmental change.

However, individuals are taking endeavors to move to renewable energy sources. Our woodlands create new oxygen and additionally help in managing temperature and precipitation. At present, timberlands cover $30 \%$ of the area, but wooded areas are being lost on a regular basis because people are looking for homes, food, and materials. Deforestation is a huge problem and will just continue to get worse. Temperature increases, like climate change, are the consequence of human practices, including the use of greenhouse gasses. When the atmosphere changes and the heat increases, it can cause a number of problems and start to destroy the world we live in. Genetic modification utilizing biotechnology is called genetic engineering. Genetic engineering of food brings about expanded poisons and sicknesses as qualities from a hypersensitive plant can exchange to target plant. Some of these crops can even be a threat to the world around us, as animals start to ingest the unnatural chemicals and such. The amount of carbon in the water and the atmosphere is continuing to be a problem in the world around us. The primary effect is on shellfish and microscopic fish, and it has similar effects to osteoporosis in humans. The current environmental concerns represent a considerable measure of danger to well-being of people, and creatures. Dirty water is the greatest well-being danger of the world and poses a risk to the health and lifespan of people and animals. The number of inhabitants in the planet is arriving at unsustainable levels as it confronts deficiency of assets like water, fuel and food. Overpopulation is one of the most important environmental concerns. Biodiversity is yet another casualty due to the impact of human beings on the environment. It is the result of 3.5 billion years of evolution. Habitat destruction is a major cause for biodiversity loss. Habitat loss is caused by deforestation, overpopulation, pollution and global warming. The over utilization of assets and formation of plastics are making a worldwide emergency of waste transfer. Developed nations are infamous for creating an unreasonable measure of waste or junk and dumping their waste in the seas and, less created nations. The ozone layer is an undetectable layer of protection around the planet that secures us from the sun's unsafe beams. Depletion of the critical Ozone layer of the air is credited to contamination brought about by Bromide and Chlorine found in Chloroform carbons (CFC's). When these poisonous gasses each the upper parts of the atmosphere, they cause a gap in the ozone layer, the greatest of which is over the Antarctic. Mining results in extraction of minerals from earth's core. These minerals also bring out harmful chemicals from deep inside the earth 
to the earth's surface. The toxic emissions from mining can cause air, water and soil pollution. Nonrenewable resources are limited and will get expired one day. Consumption of fossil fuels at an alarming rate can lead to global warming which can further result in melting of polar ice caps and increase in sea levels. Natural disasters like earthquakes, floods, tsunamis, cyclones, volcanic eruption can be unpredictable, devastating and can cause irreparable damage. They can cause huge loss of life and property. Radioactive waste is a nuclear fuel that contains radioactive substance and is a byproduct of nuclear power generation. The radioactive waste is an environmental concern that is extremely toxic and can have devastating effect on the lives of the people living nearby, if not disposed properly. Radioactive waste is considered to be harmful for humans, plants, animals and surrounding environment. Human overpopulation is prompting the elimination of species and environmental surroundings and the loss of various biomes. Environmental frameworks, which took a huge number of years to come into being, are in risk when any species populace is huge. Acid rain happens because of the vicinity of specific poisons in the climate. Corrosive downpour might be brought about because of use of fossil fuels or volcanoes or spoiling vegetation which discharge sulfur dioxide and nitrogen oxides into the air. Modern day agriculture practices make use of chemical products like pesticides and fertilizers to deal with local pests. Some of the chemicals when sprayed do not disappear and infect seeps into the ground and thereby harms plants and crops. Also, contaminated water is used for irrigation by farmers due to disposal of industrial and agricultural waste in local water bodies. Noise pollution is another common form of pollution that causes temporary disruption when there is excessive amount of unpleasant noise. Construction activities, industrialization, increase in vehicular traffic, lack of urban planning are few of the causes of noise pollution. Urban sprawl alludes to relocation of populace from high thickness urban ranges to low density provincial zones which bring about spreading of city over more rustic area. Urban sprawl brings about expanded movement, environmental concerns and well-being concerns. Medical waste is any kind of waste that is produced in large quantity by healthcare centers like hospitals, nursing homes, dental clinics and is considered to be of a bio-hazardous nature. The waste can include needles, syringes, gloves, tubes, blades, blood, body parts and many more. Littering simply means disposal of piece of garbage or debris improperly or at wrong location usually on the ground instead of disposing them at trash container or recycling bin. Littering can cause huge environmental and economic impact in the form of spending millions of dollars to clean the garbage of road that pollute the clean air. Landfills on the other hand are nothing but huge garbage dumps that make the city look ugly and produce toxic gases that could prove fatal for humans and animals. Landfills are generated due to large amount of waste that is generated by households, industries and healthcare centers every day [8].

In 2016, Europeans generated on average $480 \mathrm{~kg}$ of municipal waste per person, $46 \%$ of which was recycled or composted, while a quarter was landfilled. Municipal waste represents only around $10 \%$ of the total waste generated in the EU, but it is one of the most complex streams to manage due to its diverse composition, its large amount of producers and fragmentation of responsibilities. Legal obligations on the management of municipal waste (waste from households and similar waste) are laid down in the Waste Framework Directive. These include a $50 \%$ municipal waste preparing for re-use/recycling target to be achieved by 2020. The Directive was recently revised to include new and more ambitious targets: $55 \%$ to be achieved by $2025,60 \%$ by 2030 and $65 \%$ by 2035. The revised Directive also introduces a system of early warning reports to assess Member States' progress towards these targets three years ahead of the respective deadlines. In anticipation of this exercise, and in order to help Member States meet the 2020 target, the Commission has already conducted its first early warning study. Based on an in-depth review of Member States recycling performance and waste policies, Member States have been identified as at risk of missing the 2020 target of 50\%. These are: Bulgaria, Croatia, Cyprus, Estonia, Finland, Greece, Hungary, Latvia, Malta, Poland, Portugal, Romania, Slovakia and Spain. Construction and demolition waste is the biggest waste stream in the EU by weight, accounting for over 800 million tons per year, i.e. around $32 \%$ of the total waste generated. There is a high potential for improving resource efficiency in the management of this stream. It is made up of a mix of different materials including inert, non - inert non - hazardous and hazardous waste. It consists mainly of a mineral fraction (bricks, tiles, concrete, etc.), which is relatively 
heavy and easily recyclable, but of low value. It also contains materials with positive market value (metals) or potential value if collected separately in clean fractions (such as plastics). The Waste Framework Directive sets a 2020 target of $70 \%$ preparation for re-use, recycling and other material recovery for this waste stream. Member States' performances vary significantly, with over half reporting that they already met the 2020 target in the 2013-2015 period, and some even achieving over $90 \%$ recovery. However, Cyprus, Greece, Slovakia, and Sweden are still below 60\%. Around 10 million tons $(0.4 \%$ of the total waste produced) of waste electrical and electronic equipment (WEEE) is estimated to have been generated in the EU in 2014 - a figure which is expected to climb to more than 12 million tons by 2020. This waste stream is made up of a complex mixture of materials and components, including various substances which, if not properly managed, pose high risks to the environment and human health. Moreover, producing modern electronics requires scarce and valuable resources to be used. Directive 2012/19/EU aims at improving the collection, treatment and recycling of WEEE. During the 2013-2015 period, the amount of waste equipment collected from private households in the EU28 grew by $8 \%$. In 2014, an average of $6.21 \mathrm{~kg}$ of waste equipment per person was collected from private households. In 2015, 23 Member States met the minimum collection target of $4 \mathrm{~kg}$ of household WEEE per person, with Sweden and Denmark collecting as much as $12 \mathrm{~kg}$ while Cyprus, Latvia, Malta and Romania missed the target by a considerable margin. Since 2016, each Member State has been required to meet a collection target of $45 \%$ of equipment sold, and from 2019, that target will be $65 \%$ of equipment sold or $85 \%$ of electronic waste generated annually. Member States will be able to choose one of these two equivalent ways of measuring the target. In 2015 , the total packaging waste generated in the EU amounted to around 85 million tons, which is around $3.4 \%$ of the total waste generated. The amount of waste generated has been slowly increasing in the recent years. The Packaging Directive sets specific targets for packaging waste to be met by the end of 2008 (with time extensions for some Member States - all ceased to apply in 2015): overall recovery and recycling targets (60\% and $55 \%$, respectively) alongside material- specific recycling targets (60\% for paper and cardboard, $60 \%$ for glass, $50 \%$ for metal, $22.5 \%$ for plastic and $15 \%$ for wood). Since 2005, the average overall packaging recycling rate in the EU has steadily increased (to $65.8 \%$ in 2015). However, between 2013 and 2015 the amount of packaging waste generated grew by $6 \%$ across the EU, suggesting that more work on waste prevention is needed. The early warning study also highlighted inconsistencies in packaging data for several Member States, indicating that the amounts of packaging put on the market may be underreported. The revised Packaging Directive introduced more ambitious overall recycling targets for packaging (65\% in 2025 and $70 \%$ in 2030), and higher material - specific targets (such as $55 \%$ in 2030 for plastic). This will require increased efforts across the EU to organize separate collection schemes more efficiently in order to capture more recyclables, including through improved EPR schemes. Most Member States are meeting current overall recycling targets, although Hungary (since 2012) and Malta (since 2013) missed them by a considerable margin. Several Member States missed one or more material - specific targets: for paper and cardboard (Malta), wood (Croatia, Malta, Cyprus, Finland), metal (Croatia, Malta), and glass (Greece, Malta, Cyprus, Hungary, Portugal, Poland, and Romania). The Commission has engaged with the Member States concerned and developed targeted advice via the compliance promotion and other activities to improve performance. Landfilling is the least preferable waste treatment option. While amounts of landfilled municipal waste have steadily fallen in the EU as a whole (dropping by 18\% during the 2013-2016 period), the average landfilling rate for municipal waste in the EU still stood at $24 \%$ in 2016. Large differences across the EU persist: in 201610 Member States still landfilled over $50 \%$ of municipal waste, while five reported rates above $70 \%$. The Landfill Directive obliged Member States to reduce landfilling of municipal biodegradable waste to a maximum of $75 \%$ by $2006,50 \%$ by 2009 and $35 \%$ by 2016 , compared to a 1995 baseline. The revised Directive requires Member States to reduce the landfilling of municipal waste to a maximum of $10 \%$ by 2035 , and it introduces a ban on the landfilling of separately collected waste, including biodegradable waste. As regards meeting the targets for biodegradable waste reduction, the completeness of the data submitted by Member States varies. According to the reported data, in 2015, half of Member States had already met the $35 \%$ target for 2016. Croatia missed its $75 \%$ target which was due in 2013. Cyprus, the Czech Republic, Greece, Latvia and Slovakia missed the $50 \%$ 
target, also due in 2013. Malta, which has a high overall municipal waste landfill rate, has not reported recent data. The Commission has engaged with the Member States concerned and developed targeted advice via the compliance promotion and other activities to improve performance. A recent study carried out for the Commission found that 15 Member States were not fully meeting the obligation laid down in the Directive to treat waste before landfilling. The Sewage Sludge Directive seeks to control the use of sewage sludge in agriculture. It sets limit values for concentrations of heavy metals in sludge intended for agricultural use and soil treatment. The Directive has been in force for over 30 years and is well implemented across the EU. All Member States have set concentration limit values for heavy metals in soil that are in line with the requirements of the Directive - or indeed much stricter [9].

Climate change is already happening: temperatures are rising, rainfall patterns are shifting, glaciers and snow are melting, and the global mean sea level is rising. Most of the warming is very likely due to the observed increase in atmospheric greenhouse gas concentrations as a result of emissions from human activities. To mitigate climate change, we must reduce or prevent these emissions.

RESEARCH METHODOLOGY ANALYSIS. Europe Strategy 2020 is a key document defining the sustainable development of a particular area. The objectives are set to be implemented until 2020. This research need to present the attitudes of the respondent about the set objectives. The responders of conducted survey are 124 experts in the field of EU objectives: employment, innovation, education, social inclusion and climate/energy. The survey was conducted in the period from September until October 2018. Also, secondary (desk) analysis was conducted to see what is the current situation and indicators.

As we can see Stockholm has a most developed technology base what is crucial in smart city development. It has 24 points from maximum 37 points. The following cities are Amsterdam (22,3 points), Copenhagen (20,9 points), Barcelona (20,8 points), Helsinki (20,0 points), Vienna (18,5 points), London (17,7 points), Santander (17,4 points), Moscow (16,3 pints), Berlin (15,9 points), Hamburg (15,7 points), Paris (15,5 points) and Bristol (13,7 points). Many cities in Europe does not have advanced technologies and they are struggling with the basic infrastructures and the differences between developed and undeveloped countries/cities are getting bigger every day.

The cities that are deploying a smart application in order to became/maintain the status of smart cities are presented at list above led by London (34,5 from 55 points), Moscow (30,5 points) and Amsterdam (30,0 points).

In presented results Moscow (16,8 points), Paris (16,6 points) and Vienna (15,7 points) have the largest awareness, usage and satisfaction about applications implemented in their cities. The maximum points are 30 .

Attitudes of responders about the percentage of realized objectives of Europe Strategy 2020 are very pessimistic. The survey was conducted among 124 experts in the field of EU objectives: employment, innovation, education, social inclusion and climate/energy. Some of the responder (54 of them) think that the Strategy will be implemented between 50-69\% and 41 of them think that the Strategy will be implemented less than $50 \%$, depending on each country. Only 8 responders think that the Strategy will be realized more than $90 \%$, and they are optimist.

Also, the following restrictions have been highlighted as the main obstacles in Strategy implementation:

- Lack of information

- Insufficient interest of the population

- Insufficient co-operation and communication between the states and its population

- Lack of general culture

- Lack of sensation for the future and young generations

- Insufficient investments in development, renewable energy sources and energy efficiency

- Investing in basic infrastructure

- Lack of financial resources

- Preambitally set of objectives 


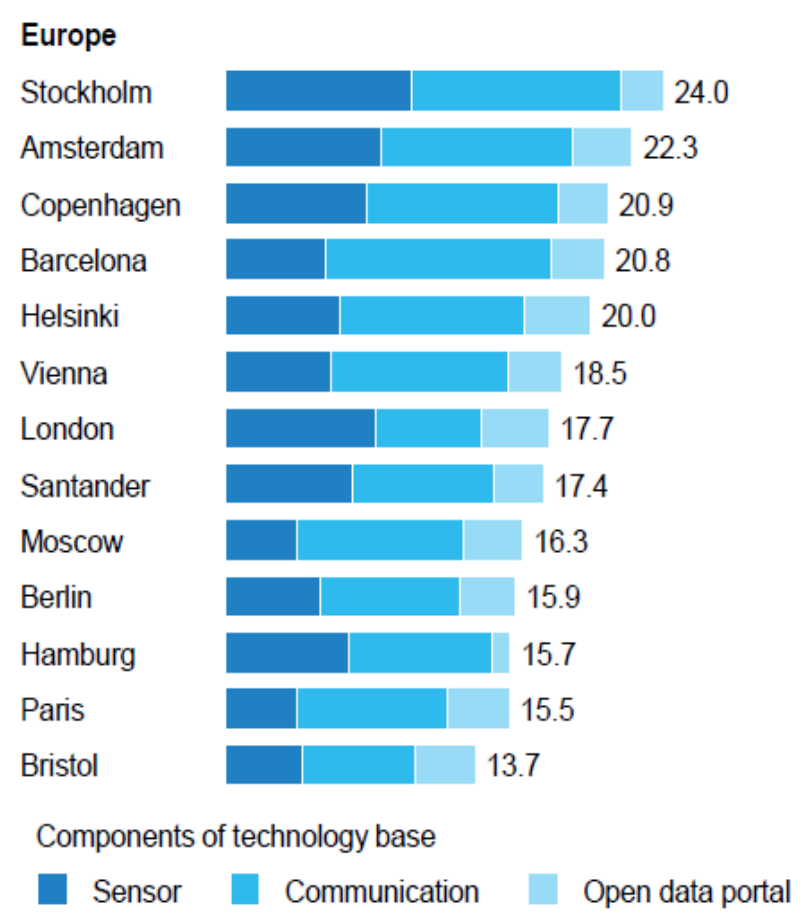

Fig. 3. Strength of smart city technology base Source: Mckinsey Global Institute, 2018 [10]

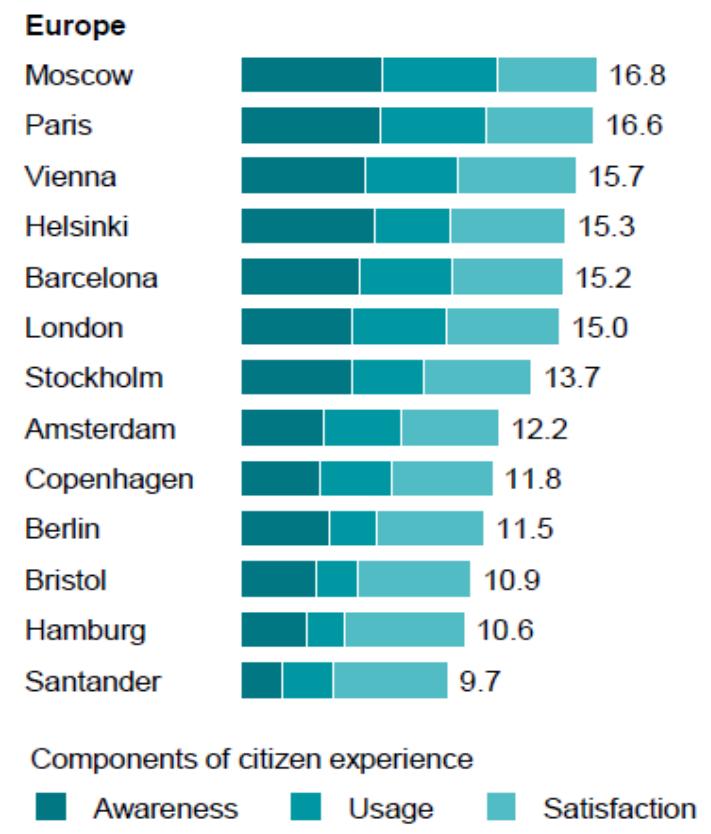

Fig. 5. Local residents' application awareness Source: Mckinsey Global Institute, 2018 [10]

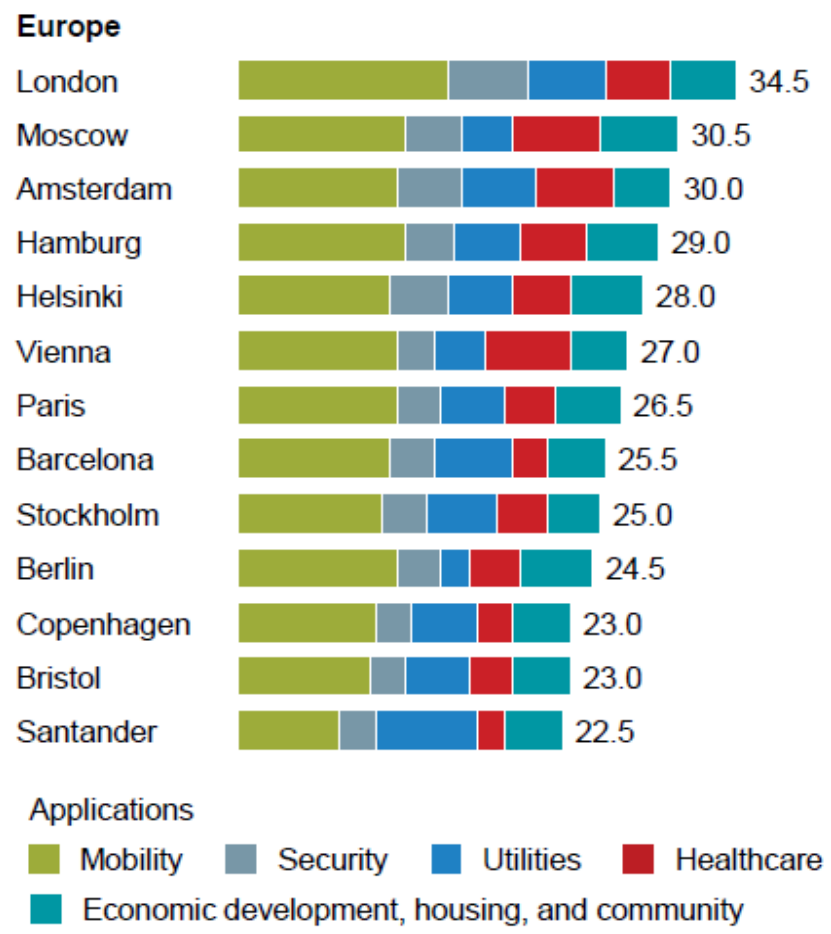

Fig. 4. The cities by deploying a smart application

Source: Mckinsey Global Institute, 2018 [10]

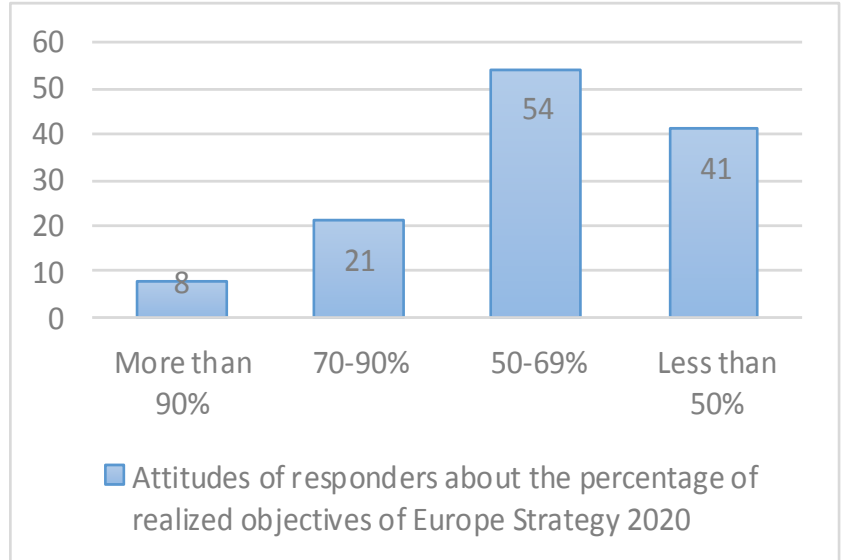

Fig. 6. Attitudes of responders about the percentage of realized objectives of Europe Strategy 2020

Source: Authors research

CONCLUSION. Europe Strategy 2020 puts forward three mutually reinforcing priorities: Smart growth, Sustainable growth, and Inclusive growth. The Commission proposes the following EU headline targets: $75 \%$ of the population aged 20-64 should be employed, $3 \%$ of the EU's GDP should be invested in R\&D, the «20/20/20» climate/energy targets should be met (including an increase to $30 \%$ of emissions reduction if the conditions are right), the share of early school leavers should be under $10 \%$ and at least $40 \%$ of the younger generation should have a tertiary degree, 20 million less people should be at risk of poverty, these targets are interrelated and critical to our overall success. The targets are representative of the three priorities of smart, sustainable and inclusive growth but they are not exhaustive: a wide range of actions at national, EU and international levels will be necessary to 
underpin them. The Commission is putting forward seven flagship initiatives to catalyze progress under each priority theme: «Innovation Union», «Youth on the move», «A digital agenda for Europe», «Resource efficient Europe», «An industrial policy for the globalization era», «An agenda for new skills and jobs», and «European platform against poverty».

The research shows that the numbers are not so good and that experts in the field of EU objectives: employment, innovation, education, social inclusion and climate/energy are not so trustable about of level of objectives implementation.

Climate change is the greatest environmental threat humanity has ever faced and the biggest challenge. It is caused by the build-up of greenhouse gases from burning fossil fuels and the destruction of areas that store massive amounts of carbon like the world's rainforests. The impacts of climate change are already being felt. Average global temperatures have risen every decade since the 1970s, and the 10 warmest years on record have all occurred since 1997. Glaciers, permafrost and sea ice are disappearing. Sea levels are rising, coral reefs dying, seasons changing and extreme weather events becoming more common. The impacts of climate change are already responsible for killing an estimated 315,000 people every year and damaging ecosystems. Climate change is a big challenge for the planet, and requires action at a large scale by all levels of government and business, but there are many things that you can do reduce your own energy consumption and promote smart energy choices in your community.

\section{References}

[1] Institute for Information Industry: Smart City Development in Taiwan: The Trend and Strength City Solution, Institute for Information Industry, 2017, available on: https://www.cdti.es/recursos/doc/Programas/Cooperacion_internacional/Taiwan/Mision_26_ marzo_2018/16287_1011012018145151.pdf, accessed: 10.01.2019.

[2] Riva Sanseverino R., "Competitive Urban Models", in Riva Sanseverino E., Riva Sanseverino R., Vaccaro V., Zizzo G. (ed.), Smart Rules for Smart Cities, Springer, Palermo, pp. 1-14, 2014.

[3] M. Milenković, M. Rašić, G. Vojković, "Using Public Private Partnership models in smart cities - proposal for Croatia", MIPRO 2017 Proceedings, Opatija, Croatia, pp. 1656-1661, 2017.

[4] M. Jong, S. Joss, D. Schraven, C. Zhan, \& M.Weijnen, "Sustainable-smart-resilient-low carbon-eco-knowledge cities; making sense of a multitude of concepts promoting sustainable urbanization", Journal of Cleaner Production, 109, pp. 25-38, 2015.

[5] United Nations ESCWA. Smart Cities: Regional Perspectives, The Government Summit Thought Leadership Series, 2015, available on: https://www.worldgovern mentsummit. org/api/publications/document/d1d75ec4-e97c-6578-b2f8-ff0000a7ddb6, accessed: 02.01.2019.

[6] European Commission. Europe 2020: Europe's growth strategy; Growing to a sustainable and job-rich future, 2012, available on: http://epan2.antagonistikotita.gr /uploads/europe_2020explained.pdf, accessed: 08.01.2019.

[7] European Commission. Europe 2020: A European strategy for smart, sustainable and inclusive growth, 2010, available on: http://ec.europa.eu/eu2020/pdf/COMPLET \%20EN\%20BARROSO\%20\%20\%20007\%20-\%20Europe\%202020\%20-20EN\%20version.pdf, accessed: 13.02.2019.

[8] Conserve Energy Future. Environmental Concerns, 2016, available on: https://www.conserveenergy- future.com/top-25-environmental-concerns.php, accessed: 12.03.2019.

[9] European Commission. Report on The Implementation of EU waste legislation, 2018, available on: http://ec.europa.eu/environment/waste/pdf/waste_legislation_implementation_report.pdf, accessed: 15.03.2019.

[10] Mckinsey Global Institute. Smart Cities: Digital Solutions for a More Liveable Future, 2018, available

on: https://www.mckinsey.com/ /media/mckinsey/industries/capital\%20projects\%20and\%20infrastr ucture/our\%20insights/smart\%20cities\%20digital\%20solutions\%20for\%20a\%20more\%20livable $\% 20$ future/mgi-smart-cities-full-report.ashx, accessed: 05.04.2019. 


\section{ВЛИЯНИЕ ЕВРОПЕЙСКОЙ СТРАТЕГИИ 2020 ГОДА И НАЦИОНАЛЬНОЙ РЕГИОНАЛЬНОЙ ПОЛИТИКИ НА РАЗВИТИЕ УМНЫХ ГОРОДОВ}

Sostar Marko, д.э.н, профессор, marko.sostar.hr@gmail.com,

Andrlic Berislav, д.э.н, профессор, bandrlic@vup.hr,

Политехникум в Пожеге, Хорватия

Попов О., к.т.н., доцент, oleg.a.popov@gmail.com, ORCID: 0000-0002-0573-9408: Одесская государственная академия строительства и архитектуры

Аннотация. Европейская Стратегия 2020 (Европа 2020) является основной программой развития ЕС в области инновационной политики и создании рабочих мест на текущее десятилетие. В ней подчеркивается разумный, устойчивый и всесторонний рост как способ преодоления структурных слабостей европейской экономики, повышения ее конкурентоспособности и производительности и поддержки устойчивой социальной рыночной экономики. «Европа 2020» определяет концепцию социальной рыночной экономики Европы на XXI век и выдвигает три взаимоусиливающих приоритета: Разумный рост: развитие экономики, основанной на знаниях и инновациях; Устойчивый рост: продвижение более ресурсоэффективной, зеленой и конкурентоспособной экономики; Инклюзивный рост: развитие экономики с высоким уровнем занятости, обеспечивающей социальную и территориальную сплоченность.

Одним из важных направлений развития в области архитектуры и экономики является грамотное развитие городов и регионов. Термин «smart sity» является общей концепцией, которая включает в себя ряд подтем, таких как разумный урбанизм, разумная экономика, устойчивая и разумная среда, разумные технологии, разумная энергия, разумная мобильность, разумное здоровье и так далее. Понятие «smart sity» выходит за рамки определений информационных городов, цифровых городов и интеллектуальных городов, поскольку оно контекстуализирует технологии, которые будут использоваться в пользу систем и услуг для людей.

Одной из ключевых целей регионального развития в городских районах является содействие сохранению климата и увеличение использования энергии из возобновляемых источников энергии. Цель работы - показать, насколько важны города для улучшения климатических условий и уменьшения негативного воздействия на окружающую среду. Полученные данные показывают влияние высоких технологий и современных прикладных решений на развитие и удовлетворенность жителей и окружающей среды.

Ключевые слова: финансирование ЕС, Европа 2020, умный город, региональное развитие, стратегия.

\section{ВПЛИВ ЄВРОПЕЙСЬКОЇ СТРАТЕГІЇ НА 2020 РІК ТА НАЦІОНАЛЬНУ РЕГІОНАЛЬНУ ПОЛІТИКУ ЩОДО РОЗВИТКУ РОЗУМНИХ МІСТ}

Sostar Marko, д.е.н, професор, marko.sostar.hr@gmail.com,

Andrlic Berislav, д.е.н, професор, bandrlic@vup.hr,

Політехнікум в Пожеге, Хорватія

Попов О., к.т.н., доцент,

oleg.a.popov@gmail.com, ORCID: 0000-0002-0573-9408:

Одеська державна академія будівництва та архітектури 
Анотація. Свропейська Стратегія 2020 (Свропа-2020) є основною програмою розвитку СС в області інноваційної політики та створенні робочих місць на поточне десятиліття. В ній підкреслюється розумне, стійке і всебічне зростання як спосіб подолання структурних слабкостей європейської економіки, підвищення iї конкурентоспроможності та продуктивності і підтримки стійкої соціальної ринкової економіки. «Свропа 2020» визначає концепцію соціальної ринкової економіки Європи на XXI століття і висуває три взаємопідсилюючих пріоритети: Розумне зростання: розвиток економіки, заснованої на знаннях і інноваціях; Стійке зростання: просування більш ресурсоефективної, зеленої і конкурентоспроможної економіки; Інклюзивне зростання: розвиток економіки з високим рівнем зайнятості, що забезпечує соціальну і територіальну згуртованість.

Одним з важливих напрямків розвитку в області архітектури і економіки є грамотний розвиток міст і регіонів. Термін «smart sity»є спільною концепцією, яка включає в себе ряд підтем, таких як розумний урбанізм, розумна економіка, стійке і розумне середовище, розумні технології, розумна енергія, розумна мобільність, розумне здоров'я і так далі. Поняття «smart sity» виходить за рамки визначень інформаційних міст, цифрових міст $\mathrm{i}$ інтелектуальних міст, оскільки воно контекстуаналізує технології, які будуть використовуватися на користь систем і послуг для людей.

Однією 3 ключових цілей регіонального розвитку в міських районах $є$ сприяння збереженню клімату і збільшення використання енергії з відновлюваних джерел. Мета роботи - показати, наскільки важливі міста для поліпшення кліматичних умов і зменшення негативного впливу на навколишнє середовище. Отримані дані показують вплив високих технологій i сучасних прикладних рішень на розвиток i задоволеність жителів i навколишнього середовища.

Ключові слова: фінансування $С$, Свропа 2020, розумне місто, регіональний розвиток, стратегія.

Стаття надійшла 21.11.2019 